\title{
SIMULASI NUMERIK KUAT LEKAT TULANGAN BAJA DAN BETON DENGAN PROGRAM ABAQUS STUDENT EDITION (SE)
}

\author{
NGUDIYONO $^{1 *}$, HARIYADI ${ }^{1}$, Yuana Pratiwi NINGSIH ${ }^{2}$ \\ ${ }^{1}$ Jurusan Teknik Sipil, Fakultas Teknik, Universitas Mataram, Mataram, Indonesia \\ ${ }^{2}$ Alumni Jurusan Teknik Sipil, Fakultas Teknik, Universitas Mataram, Mataram, Indonesia \\ *Email korespondensi: ngudiyono@unram.ac.id
}

[diterima: 24 Maret 2021, disetujui: 24 Mei 2021]

\begin{abstract}
In the reinforced concrete structural elements, bond strength between steel reinforcement and concrete is as important as the compressive strength of concrete. Bonding between steel reinforcement and concrete is one of the important factors affecting the behavior of reinforced concrete elements, especially when experiencing cracks. Experimental and numerical studies with computer programs based on the finite element method (FEM) have been carried out by many previous researchers, however the studies that have been carried out are still using one type of diameter variation, while numerical modeling with variations in the diameter of reinforcement has never been carried out. In this numerical simulation with ABAQUS SE, the pull out test specimen from the results of previous research is a cylindrical concrete specimen with dimensions of $150 \mathrm{~mm} \times 300 \mathrm{~mm}$ and diameter of reinforcement $(d) 10 \mathrm{~mm}, 13 \mathrm{~mm}, 16$ $\mathrm{mm}, 19 \mathrm{~mm}$ with development length $(l=10 d) 100 \mathrm{~mm}, 130 \mathrm{~mm}, 160 \mathrm{~mm}, 190 \mathrm{~mm}$, respectively. The specimen was modeled with 2 dimension (2D) one quarter circle (axisymmetric), the interaction of steel reinforcement and concrete was modeled as a cohesive behavior. The numerical simulation results show that the larger the diameter of the steel reinforcement used, the lower the bond strength value between the steel reinforcement and concrete, the axisymmetric and cohesive behavior models can be used to model the interaction of steel and concrete reinforcements, with good level of accuracy, where the difference in the value of bond strength, from modeling and experiment are between $0.35 \%-2.231 \%$.
\end{abstract}

Key words: Bond Strength, diameter of steel reinforcement, ABAQUS SE, cohesive behavior.

\section{INTISARI}

Pada elemen struktur beton bertulang, kuat lekat antara tulangan baja dan beton sama pentingnya dengan kuat tekan beton. Lekatan antara tulangan baja dan beton adalah salah satu faktor penting yang mempengaruhi perilaku elemen beton bertulang terutama pada saat mengalami keretakan. Kajian-kajian secara ekperimen dan numerik dengan program komputer berbasis metode elemen hingga (FEM) telah banyak dilakukan oleh peneliti sebelumnya, namun kajian-kajian yang telah dilakukan masih menggunakan satu jenis variasi diameter, sedangkan pemodelan secara numerik dengan variasi diameter tulangan belum pernah dilakukan. Pada simulasi numerik dengan ABAQUS SE ini benda uji pengujian pull out dari hasil penelitian sebelumnya yaitu benda uji beton berbentuk silinder dengan dimensi $150 \mathrm{~mm}$ x $300 \mathrm{~mm}$ dan diameter tulangan $(d) 10 \mathrm{~mm}, 13 \mathrm{~mm}, 16 \mathrm{~mm}, 19 \mathrm{~mm}$ dengan panjang penyaluran $(\mathrm{l}=10 \mathrm{~d})$ berturut turut $100 \mathrm{~mm}, 130 \mathrm{~mm}, 160 \mathrm{~mm}, 190 \mathrm{~mm}$. Benda uji dimodelkan dengan 2 dimensi (2D) satu perempat lingkaran (axisymmetric) interaksi tulangan baja dan beton dimodekan sebagai cohesive behavior. Hasil simulasi numerik menunjukkan bahwa semakin besar diameter tulangan baja yang digunakan, nilai kuat lekat antara tulangan baja dan beton semakin menurun, model axisymmetric dan cohesive behavior dapat digunakan untuk memodelkan interaksi tulangan baja dan beton, dengan tingkat keakuratan cukup baik, dimana selisih nilai kuat lekat hasil pemodelan dan eksperimen yaitu antara $0.35 \%-2.231 \%$.

Kata kunci: Kuat lekat, diameter tulangan baja, ABAQUS SE, cohesive behavior. 


\section{PENDAHULUAN}

Kuat lekat antara tulangan baja dan beton sama pentingnya dengan kuat tekan beton, dimana akan mempengaruhi perilaku elemen beton bertulang terutama pada saat mengalami keretakan. Salah satu faktor yang mempengaruhi kuat lekat antara tulangan baja dan beton diantaranya yang penting adalah diameter tulangan baja. Faktor ini telah dibuktikan secara ekperimental oleh Hamdy dan El-Tony (2015); Wulandari (2019); Faye et al., (2017) semakin besar diameter tulangan baja yang digunakan nilai kuat lekat yang dihasilkan semakin kecil.

Kajian secara numerik kuat lekat tulangan baja dan beton dengan software berbasis metode elemen hingga (finite element method) seperti ABAQUS, ANSYS telah dilakukan oleh Nardin et al., (2005); Juan and Benson Shing (2014); Camille and Omar (2015); Kabir et al., (2015); Molina et al., (2015); Pereira et al., (2015); Beliave et al., (2016); Seok et al., (2018); Senthil et al., (2018); Gujar et al., (2019). Kajian-kajian numerik tersebut menunjukkan bahwa kuat lekat tulangan baja dan beton dapat dimodelkan sebagai contact problem, dimana interaksi antara tulangan baja dan beton dapat diasumsikan berperilaku kohesif (cohesive behavior) yang dapat menggambarkan lepasnya ikatan antara beton dengan tulangan baja. Dengan menggunakan hubungan tegangan dan slip pada hasil eksperimen dapat di hitung perilaku kohesif dari interaksi antara tulangan baja dan beton, sehingga pemodelan yang dilakukan dapat menunjukkan hasil yang memuaskan. Namun, kajian-kajian yang telah dilakukan masih menggunakan satu jenis variasi diameter, sedangkan pemodelan dengan variasi diameter tulangan belum pernah dilakukan.

\section{SIMULASI NUMERIK DENGAN PROGRAM ABAQUS STUDENT EDITION (SE)}

Simulasi numerik dengan program ABAQUS Student Editon (SE) secara ringkas biasanya terdiri dari tiga tingkat, yaitu preprocessing, simulasi, dan postprocessing seperti yang ditunjukkan pada Gambar 1.

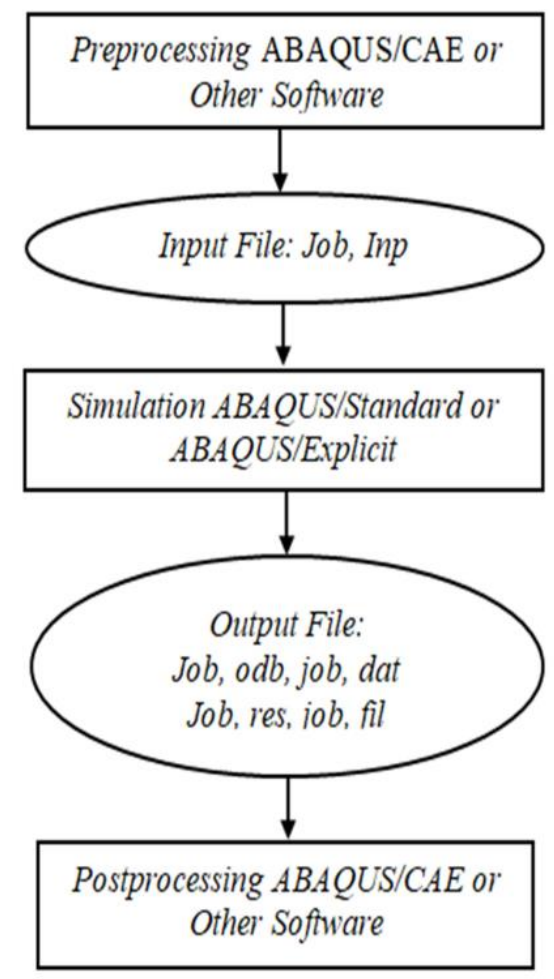

Gambar 1. Diagram Alir Program ABAQUS SE (ABAQUS, 2018)

Program ABAQUS Student Editon (SE) mampu memecahkan masalah yang berhubungan dengan masalah contact problem, seperti interaksi tulangan baja dan beton. Untuk menentukan hubungan antara bond slip (lekatan slip) dapat menggunakan hukum traction separation (Gambar 2). Hukum ini, dapat digunakan untuk mengetahui adanya kerusakan pada beton yang disebabkan oleh naiknya traksi secara linear hingga nilai maksimum, dengan capaian $\left(t^{0} n\left(t^{0} s, t^{0} t\right), \delta^{0} n\left(\delta^{0} s, \delta^{0} t\right)\right.$. Pada bagian yang menurun menandakan bahwa adanya kerusakan pada beton dan kerusakan ini mengakibatkan turunnya kekuatan lekat antara tulangan dan beton, hingga traksi yang terjadi 
adalah nol. Perilaku kohesif (cohesive behavior) lekatan antara tulangan dan beton dapat ditulis dalam persamaan matrik (1).

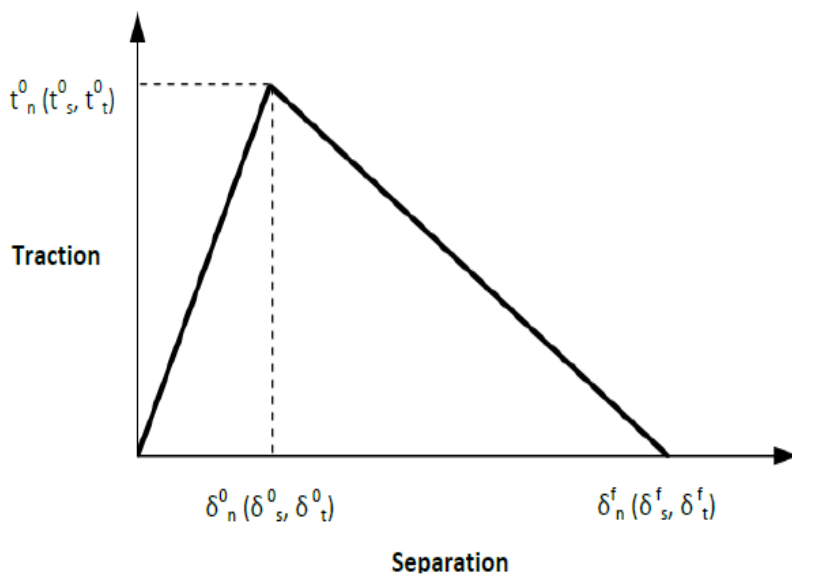

Gambar 2. Hukum traction separation (ABAQUS, 2018)

$$
T=\left\{\begin{array}{l}
t_{n} \\
t_{s} \\
t_{t}
\end{array}\right\}=\left[\begin{array}{ccc}
K_{n n} & 0 & 0 \\
0 & K_{s s} & 0 \\
0 & 0 & K_{t t}
\end{array}\right]\left\{\begin{array}{l}
\delta_{n} \\
\delta_{s} \\
\delta_{t}
\end{array}\right\}=K \delta
$$

Dalam Persamaan (1), $T$ adalah vektor tegangan traksi nominal terdiri dari tiga komponen yaitu $t_{n}, t_{s}$, dan $t_{t}$, dimana tiap komponen mewakili traksi normal dan dua geser. Begitu juga dengan vektor perpindahan $(\delta)$ terdiri dari tiga komponen yaitu $\delta_{n}, \delta_{s}$, dan $\delta$, masing-masing merupakan perpindahan terkait arah normal dan transversal dan $K_{n n}$, $K_{s s}$ dan $K_{t t}$ merupakan koefisien kekakuan. Nilai $K_{s s}$ dan $K_{t t}$ diperoleh dari perkiraan hubungan antara lekatan versus slip yang diperlihatkan pada Gambar 3 dan dinyatakan dalam Persamaan (2) dan kekakuan traksi normal lebih besar daripada arah geser seperti yang dinyatakan dalam Persamaan (3).

$$
\begin{aligned}
& K_{t t}=\frac{\tau_{\max }}{s_{1}} \\
& K_{n n}=100 K_{s s}
\end{aligned}
$$

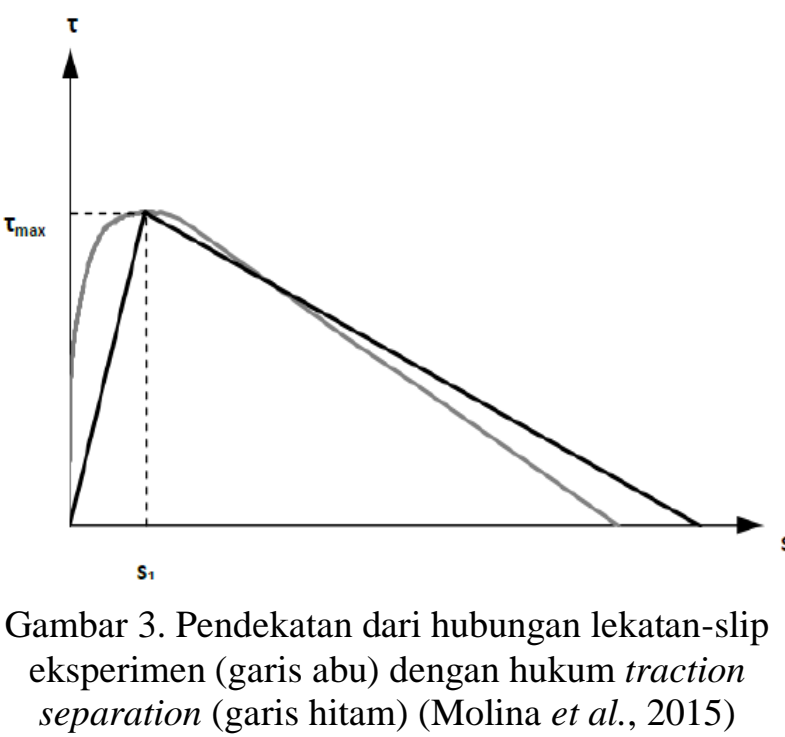

\section{METODE ANALISA}

\section{Data Ekperimen}

Data-data yang digunakan untuk analisa nuemrik ini adalah data hasil penelitian pengujian pull out yang telah dilakukan oleh Wulandari (2019), meliputi data ukuran silinder beton, diameter tulangan baja $(d)$, tegangan leleh (fy), modulus elastisitas tulangan baja $(E s)$ jenis beton, mutu beton $\left(f^{\prime} c\right)$, modulus elastisitas beton $(E c)$ dan hubungan antara lekatan versus slip diameter tulangan baja (d) yang dgunakan adalah 10 $\mathrm{mm}, 13 \mathrm{~mm}, 16 \mathrm{~mm}$ dan $19 \mathrm{~mm}$ dengan tegangan leleh (fy) berturut turut $456 \mathrm{MPa}$, $431 \mathrm{MPa}, 324 \mathrm{MPa}$, dan $381 \mathrm{MPa}$, sedangkan modulus elastisitas tulangan baja (Es) diasumsikan $200000 \mathrm{MPa}$. Kuat tekan $\left(f^{\prime} c\right)$ dan modulus elastisitas $(E c)$ yang digunakan adalah 47.797 $\mathrm{MPa}$ dan 39979.214 $\mathrm{MPa}$. Sedangkan parameter poison rasio untuk tulangan baja diasumsikan 0.3 dan 0.15 .

Pada penelitian ini interaksi tulangan baja dan beton diasumsikan berperilaku sebagai material kohesif (cohesive behavior) yang diperoleh dari perhitungan berdasarkan persamaan (2) dan persamaan (3), hasil analisa disajikan pada Tabel 1. 
Tabel 1. Parameter cohesive behavior (Wulandari, 2019)

\begin{tabular}{ccccc}
\hline Parameter & $d=10 \mathrm{~mm}$ & $d=13 \mathrm{~mm}$ & $d=16 \mathrm{~mm}$ & $d=19 \mathrm{~mm}$ \\
\hline$K_{s s}$ & $0.95782 \mathrm{~N} / \mathrm{mm}$ & $0.55584 \mathrm{~N} / \mathrm{mm}$ & $0.26966 \mathrm{~N} / \mathrm{mm}$ & $0.1569 \mathrm{~N} / \mathrm{mm}$ \\
$K_{t t}$ & $0.95782 \mathrm{~N} / \mathrm{mm}$ & $0.55584 \mathrm{~N} / \mathrm{mm}$ & $0.26966 \mathrm{~N} / \mathrm{mm}$ & $0.1569 \mathrm{~N} / \mathrm{mm}$ \\
$K_{n n}$ & $95.7817 \mathrm{~N} / \mathrm{mm}$ & $55.5837 \mathrm{~N} / \mathrm{mm}$ & $26.9661 \mathrm{~N} / \mathrm{mm}$ & $15.6897 \mathrm{~N} / \mathrm{mm}$ \\
\hline
\end{tabular}

\section{Pemodelan}

Pada pengujian pull out yang dilakukan Wulandari (2019), benda uji yang digunakan adalah beton silinder dengan dimensi $150 \mathrm{~mm}$ x $300 \mathrm{~mm}$ dan diameter tulangan yang digunakan adalah diameter $(d) 10 \mathrm{~mm}, 13$ $\mathrm{mm}, 16 \mathrm{~mm}, 19 \mathrm{~mm}$ dengan panjang penyaluran $(l=10 d)$ berturut turut $100 \mathrm{~mm}$, $130 \mathrm{~mm}, 160 \mathrm{~mm}, 190 \mathrm{~mm}$. Pada simulasi numerik dengan ABAQUS SE benda uji dibuat dalam bentuk 2 dimensi (2D) satu perempat lingkaran (axisymmetric). Gambar struktur yang dimodelkan ditunjukkan dalam Gambar 5, sedangkan model axisymmetric disajikan pada Gambar 6. Analisis statik dilakukan dengan metode control displacement, yaitu dengan memberikan beban displacement untuk mendapatkan nilai kekuatan maksimum model. Beban displacement yang diberikan untuk diameter $10 \mathrm{~mm}, 13 \mathrm{~mm}, 16 \mathrm{~mm}$ dan $19 \mathrm{~mm}$ berturutturut $25 \mathrm{~mm}, 15 \mathrm{~mm}, 21 \mathrm{~mm}$ dan $25 \mathrm{~mm}$ dengan increment $0.1 \mathrm{~mm}$. Kuat lekat maksimum ditentukan dari beban cabut/tarik maksimum yang mampu diterima oleh benda uji.

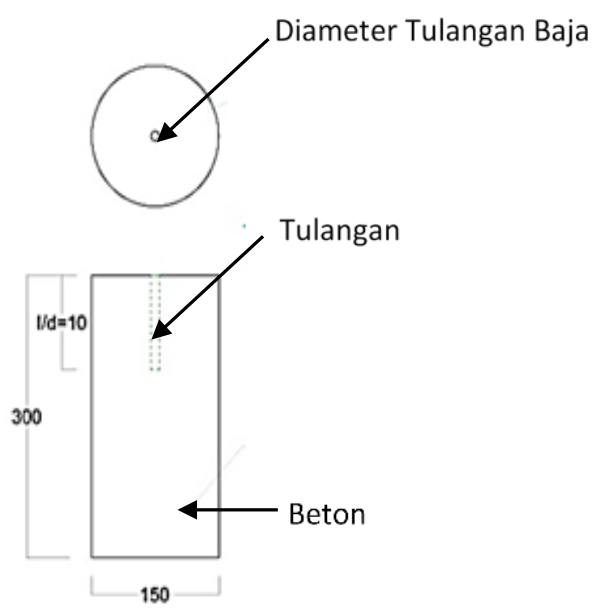

Gambar 5. Benda uji eksperimen

(Wulandari, 2019)

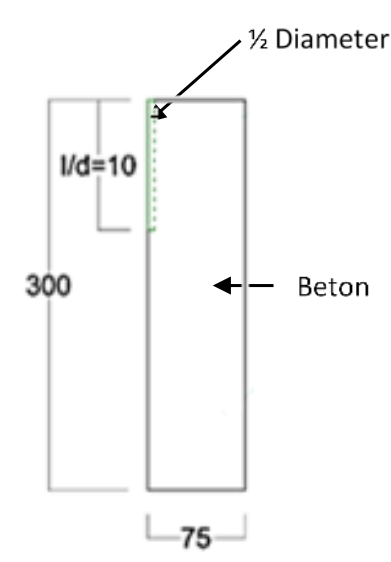

(a)

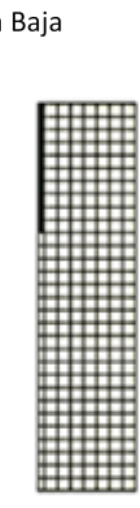

(b)
Gambar 6. Model axisymmetric (a) Geometri 2D (b) Meshing

\section{HASIL DAN PEMBAHASAN}

\section{Kuat Lekat}

Berdasarkan pemodelan dengan metode control displacement diperoleh nilai tegangan lekat pada beton mutu tinggi dengan variasi diameter $10 \mathrm{~mm}, 13 \mathrm{~mm}, 16 \mathrm{~mm}$ dan $19 \mathrm{~mm}$ berurut sebesar $13.40 \mathrm{MPa}, 8.335 \mathrm{MPa}, 5.662$ $\mathrm{MPa}, 3.922 \mathrm{MPa}$ (lihat Gambar 7, 8, 9, dan 10). Perbandingan tegangan lekat beton mutu tinggi hasil analisis dan ekperimen disajikan pada Gambar 11, terlihat bahwa antara hasil pemodelan dan ekperimen perbedaanya tidak terlalu siknifikan, selisih antara pemodelan dengan eksperimen berturut-turut adalah $0.425 \%, 0.56 \%, 2.231 \%, 0.35 \%$.

Dari pemodelan kuat lekat juga dapat juga diperoleh grafik hubungan kuat lekat dan deformasi (slip) tulangan baja dan beton, perbandingan antara hasil pemodelan dan eksperimen ditunjukkan pada Gambar 12. 


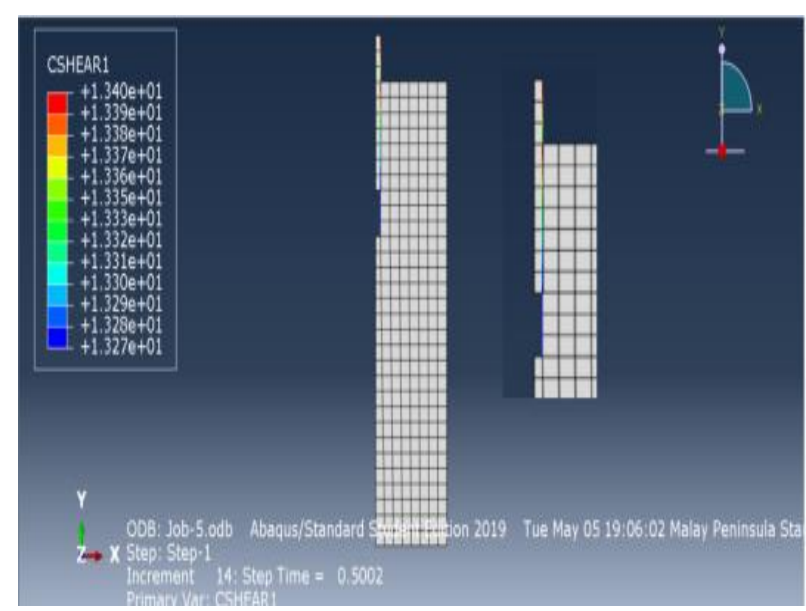

Gambar 7. Kuat lekat yang terjadi pada tulangan diameter $10 \mathrm{~mm}$

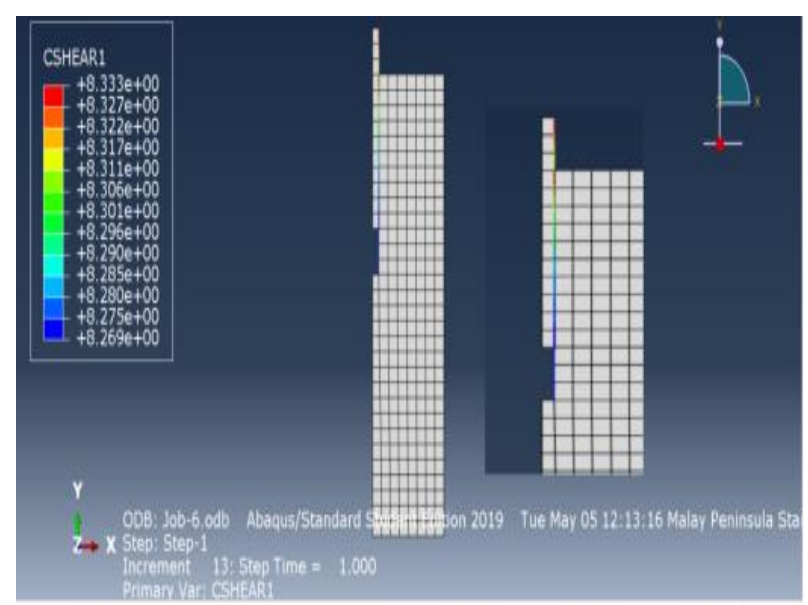

Gambar 8. Kuat lekat yang terjadi pada tulangan diameter $13 \mathrm{~mm}$

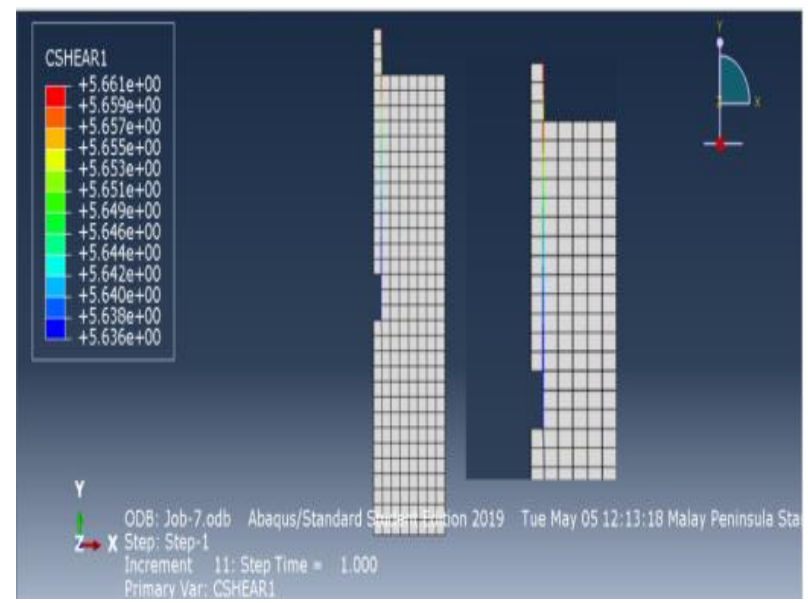

Gambar 9. Kuat lekat yang terjadi pada tulangan diameter $16 \mathrm{~mm}$

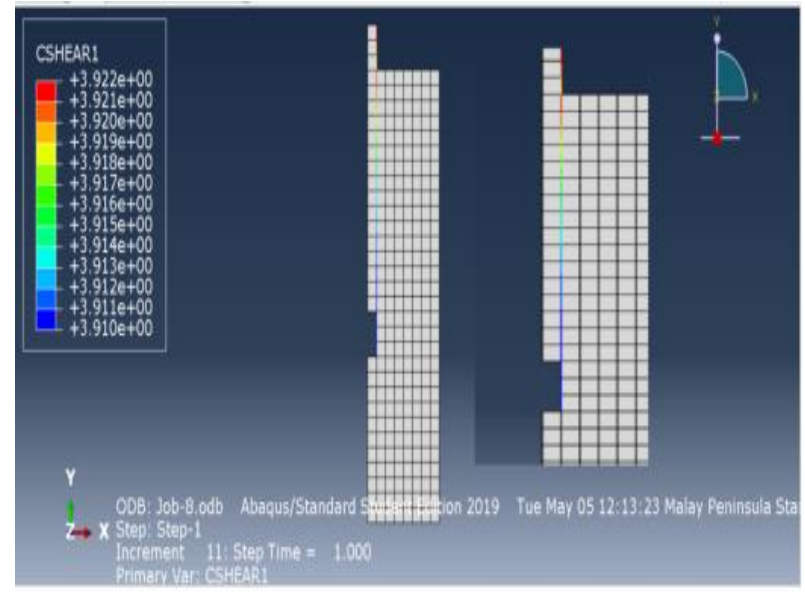

Gambar 10. Kuat lekat yang terjadi pada tulangan diameter $19 \mathrm{~mm}$

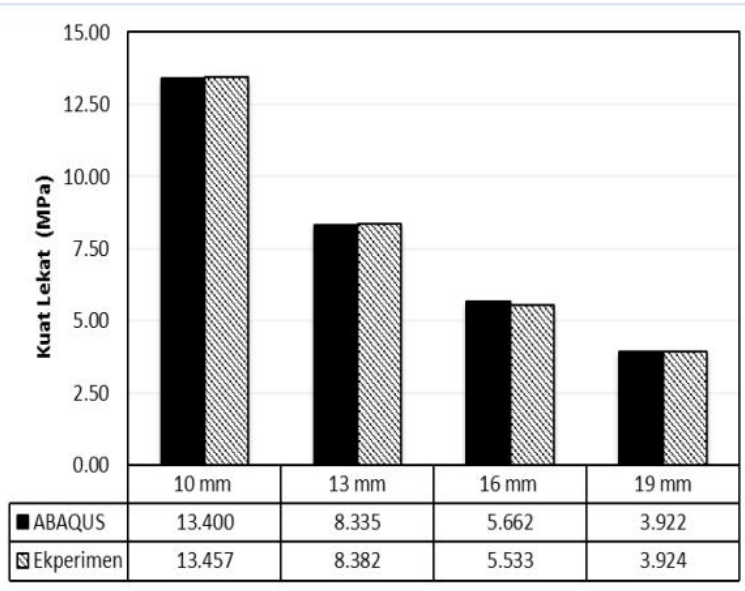

Gambar 11. Perbandingan kuat lekat ekperimen dan pemodelan

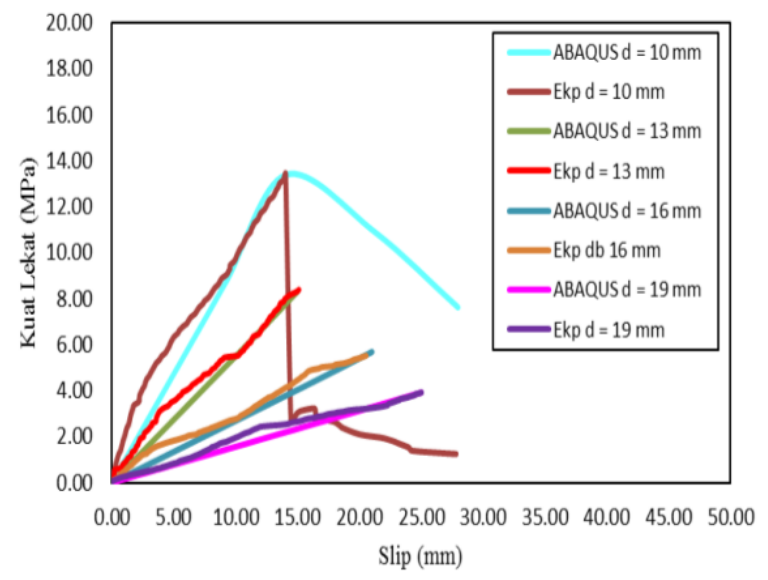

Gambar 12. Hubungan kuat lekat vs slip ekperimen dan pemodelan 


\section{Pola Keruntuhan}

Secara numerik pola keruntuhan yang terjadi untuk tulangan baja diameter $10 \mathrm{~mm}$, $13 \mathrm{~mm}, 16 \mathrm{~mm}$, dan $19 \mathrm{~mm}$ ditunjukkan pada Gambar 13 sampai dengan Gambar 16. Meskipun dalam preprocessing, simulasi, dimodelkan secara 2D axisymmetric, namun dalam postprocessing ABAQUS SE mampu menampilkan tegangan yang terjadi secara 3D, seperti yang disajikan pada Gambar 13 sampai Gambar 16.

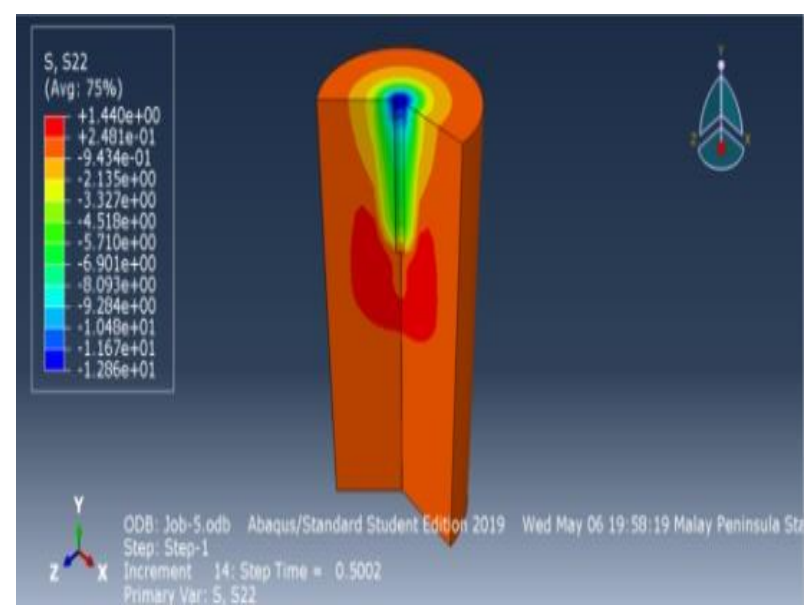

Gambar 13. Pola keruntuhan yang terjadi pada beton dengan diameter tulangan $10 \mathrm{~mm}$

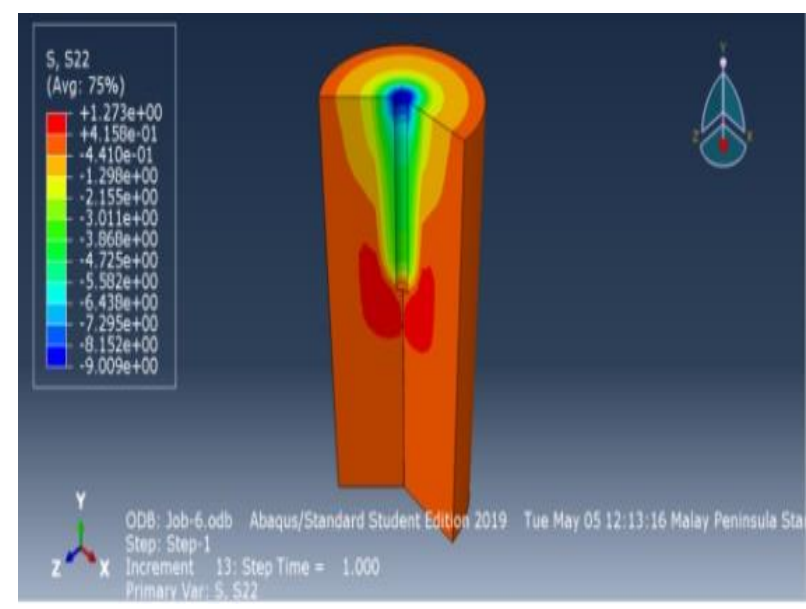

Gambar14. Pola keruntuhan yang terjadi pada beton dengan diameter tulangan $13 \mathrm{~mm}$

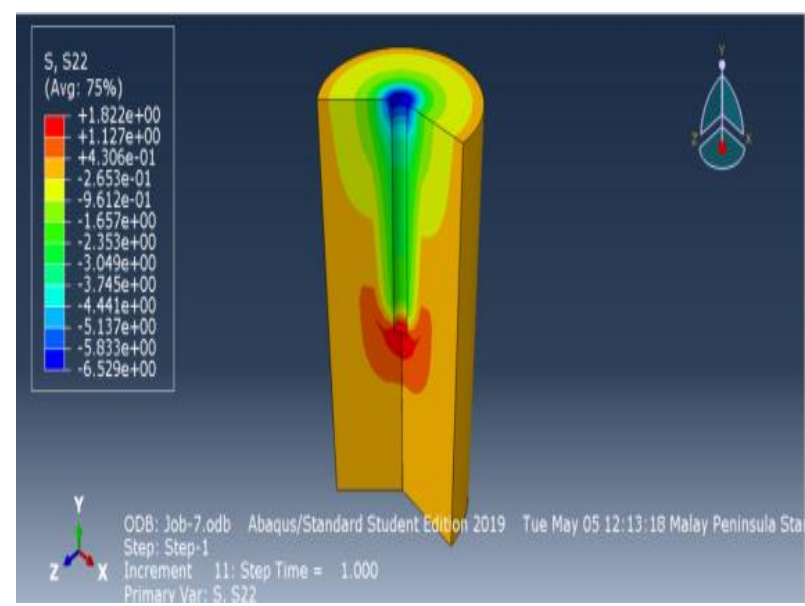

Gambar 15. Pola keruntuhan yang terjadi pada beton dengan diameter tulangan $16 \mathrm{~mm}$

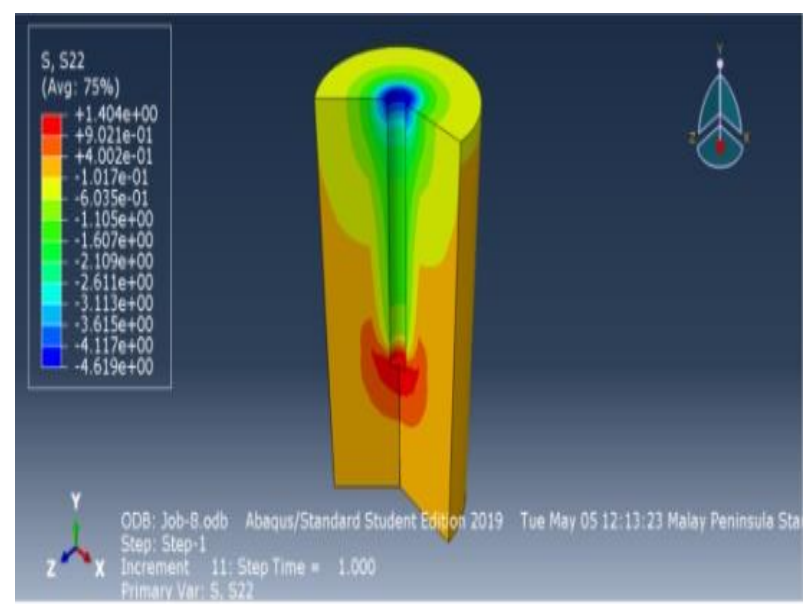

Gambar 16 Pola keruntuhan yang terjadi pada beton dengan diameter tulangan $19 \mathrm{~mm}$

Dari Gambar 13 sampai dengan Gambar 16, terlihat bahwa semakin besar diameter tulangan baja yang digunakan, maka tegangan yang terjadi pada beton disekitar tulangan semakin kecil. Hal ini disebabkan oleh semakin besar diameter maka luas bidang lekatan semaki luas, sehingga tegangan yang terjadi juga semakin kecil. Hasil simulasi juga menunjukkan bahwa beton disekitar tulangan mengalami gaya desak/tekan, sehingga tegangan yang terjadi pada model dengan tulangan baja diameter $10 \mathrm{~mm}, 13 \mathrm{~mm}, 16 \mathrm{~mm}$ dan $19 \mathrm{~mm}$ berturut-turut adalah $12.86 \mathrm{MPa}, 9$ $\mathrm{MPa}, 6.52 \mathrm{MPa}$ dan 4.62 MPa. 


\section{KESIMPULAN}

Dari simulasi numerik kuat lekat tulangan baja dan beton dengan menggunakan program ABAQUS SE, dapat disimpulka bahwa semakin besar diameter tulangan baja yang digunakan, nilai kuat lekat antara tulangan baja dan beton semakin menurun. Model axisymmetric dan cohesive behavior dapat digunakan untuk memodelkan interaksi tulangan baja dan beton, sehingga dapat diperoleh hubungan kuat lekat dengan variasi diameter tulangan baja. Tingkat keakuratan pemodelan numerik menggunakan program ABAQUS SE cukup baik, dimana selisih nilai kuat lekat hasil pemodelan dan eksperimen yaitu antara $0.35 \%-2.231 \%$.

Program ABAQUS SE merupakan software free lisensi yang dapat digunakan untuk para mahasiwa, dosen dan peneliti untuk kegiatan pendidikan dan penelitian/publikasi. Program ini memiliki keterbatasan hanya mampu menganalisa sampai 1000 node, sehingga diperlukan strategi khusus dalam menentukan jenis pemodelan, tipe elemen dan meshing.

\section{UCAPAN TERIMA KASIH}

Ucapan terima kasih disampaikan kepada Laboratorium Struktur, Jurusan Teknik Sipil, Universitas Mataram dan Saudari Wulandari yang telah menyediakan data ekperimen sebagai data pembanding dalam simulasi numerik ini.

\section{REFERENSI}

ABAQUS, 2018. Analysis User's Guide Volume IV: Element, USA.

Beliaev, M., Semenov, A., Semenov, S., and Benin, A., 2016. Simulation of Pulling Bar from Concrete Block with Account of Friction and Concrete Demage. MATEC Web of Conferences. 73: 1-7.

Bilek, V., Bonezkova, S., Semenov, S., Hurta, J., Pytlik, D., and Mrovec, M., 2017. Bond Strenght Between Reinforcing Steel and Different Types of Concrete. Procedia Engineering. 190: 243-247.

Camille, A. I., and Omar, M., 2015. Numerical Simulation of the Bond Behavior between Concrete and Steel Reinforcing Bars in Specialty Concrete. International Journal of Civil and Environmental Engineering. 9 (6): 767-774.

Faye, P.N., Ye, Y., and Diao, B., 2017. Bond Effects between Concrete and Steel Bar Using Different Diameter Bars and Different Initial Crack Width. Hindawi Advances in Civil Engineering. April: 111.

Gujar, A., Pore, S., and Prakash, V., 2019. Modeling in ABAQUS fot Experimental Investigation of Multi-linear Bond Slip Properties ib Reinforce Concrete. SJIF. 6 (March): 155-163.

Hamdy, M.A., and El-Tony M., 2015. Bond Behavior of Embedded Reinforcing Steel Bars for Varying Levels of Transversal Pressure. Journal of Performance of Constructed Facilities. September: 1-10.

Juan, M. D., and Benson Shing, P. B., 2014. Bond-Slip Model for Detailed FiniteElement Analysis of Reinforced Concrete Structures. Journal of Structural Engineering. July (14): 1-10.

Kabir, M.R., Islam, M.M., and M.A. Chowdhury., 2015. Bond stress-slip behavior between concrete and steel rebar via pullout test: experimental and finite element analysis. First International Conference on Advances in Civil Infrastructure and Construction Materials. December: 1-10.

Molina, L., Javier, F., Ruiz, F., Alejandro, M., Montes, H., Enrique., Alonso, A., Cruz, M., 2015. Bond strength of Galvanzed Steel: Experimental and Numerical Study Based on Pull-Out Tests. CMMoST. June: 143-158.

Nardin, D.S., Filho. A.F.M., and Filho, O.J., 2005. Non-Linier Analysis of The Bond Strengh Behavior on The Steel-Concrete Interface by Numerical Models Ans Pull- 
Out Test. Structures Congress. April: 112.

Pereira, H.F.S.G., 2015. Numerical Simulation of Galvanized Rebars Pullout. Frattura ed Integrità Strutturale. 31: 54-66.

Seok, S., Haikal, G., Ramirez, J. A., Laura N. Lowes, L. N., 2018. High-resolution finite element modeling for bond in highstrength concrete beam. Engineering Structures. 173: 918-932.

Senthil, K., Bawa, S., and Aswin, C. P., 2018. Influence of concrete strength and diameter of reinforcing bar on pullout tests using finite element analysis, Journal of Structural Engineering \& Applied Mechanics. 1(3): 105-116.

Wulandari, S., 2019. Pengaruh Variasi Diameter Tulangan Baja Ulir Terhadap Kuat Lekat (Bond Strenght) Pada Beton Mutu Tinggi, Beton Normal dan Beton Ringan. Skripsi, Jurusan Teknik Sipil, Fakultas Teknik Universitas Mataram, Mataram. 